DOI $10.15421 / 4220017$

УДК 539.3

\author{
Х. І. Середницька, канд. фріз.-мат. ннаук
}

\title{
ЗАДАЧА ТЕРМОПРУЖНОСТІ ДЛЯ ЗАКРИТОЇ МІЖФАЗНОЇ ТЕПЛОІЗОЛЬОВАНОЇ ЩІЛИНИ В РІЗНОРІДНОМУ БІМАТЕРІАЛІ
}

\begin{abstract}
Досліджено поведінку різнорідного біматеріалу 3 міжфазною теплоізольованою щілиною, береги якої контактують по усій довжині під дією стискальних зусиль і однорідного теплового потоку. Задачу термопружності зведено до системи сингулярних інтегро-диференціальних рівнянь відносно стрибка температури та зсувних переміщень берегів щілини. Отриману систему розв'язано для біматеріалу, складеного 3 сплаву нікелю та неіржавіючої сталі. Визначено контактний тиск берегів щілини і порогові значення стискальних зусиль, для яких відбувається повне закриття щілини. Проаналізовано вплив теплового потоку на коефіцієнт інтенсивності дотичних напружень.
\end{abstract}

Ключові слова: термопружність; різнорідний біматеріал; міжфазна щілина; закриття щілини; стискальні зусилля; тепловий потік.

Вступ. В реальних матеріалах внаслідок різних фрізико-механічних та хімічних процесів відбувається зміна структури поверхонь тіл та поява різного роду десректів. Врахування мікроструктури поверхонь $\epsilon$ важливим при дослідженні механічної поведінки матеріалів, оскільки мікронерівності у вигляді тріщин чи нерівностей поверхонь самих тріщин зумовлюють дискретність контакту, фактична площа якого залежить від контактного тиску і змінюється зі зміною навантаження [11]. Контактні задачі для тріщин вивчено з врахуванням шорсткості поверхонь $[8,13]$, наявності тонких шарів $[12,15,16]$ і заповнювача зазорів [10] під дією механічного навантаження. Вплив термічного навантаження на контакт берегів дефектів має місце для композитних матеріалів [9]. Тут мікроструктура поверхні врахована у термічній провідності або термоопорі дефекту. Термопружність кусково-однорідного тіла із закритою міжфазною тріщиною при наявності контактного термоопору між їі берегами вивчено у [2]. Закриття тріщини під дією зосередженої сили проаналізовано для однорідного матеріалу [3]. Закриття тріщини під дією рівномірно розподіленого стискального навантаження і однорідного теплового потоку вивчено для біматеріалу, компоненти якого відрізняються лише модулями зсуву [4]. В останніх працях враховано залежність контактного теплообміну від шорсткості поверхонь. У $[1,5]$ враховано вплив тонких плівок і заповнювача тріщини на частковий контакт іï берегів під дією теплового потоку і розтягувального навантаження у біматеріалі з нульовим параметром Дандерса. У

() Х. І. Середницька, 2020 
наведених працях дослідження в основному проведені для таких біматеріалів, характеристики яких були частково змінними, зокрема відрізнялися лише модулями зсуву, коефіцієнтами Пуассона або механічні характеристики однакові і т. п. Контактні задачі для різнорідних тіл, що містять міжфазні тріщини досліджено у постановці контакту берегів на привершинних ділянках під дією механічного і електричного навантаження [7, 14].

В даній статті на прикладі біматеріалу, в якому поєднано сплав нікелю та неіржавіюча сталь, досліджено термомеханічну поведінку різнорідного біматеріалу з міжфазною теплоізольованою щілиною, що повністю закривається під дією стискального навантаження та стаціонарного однорідного теплового потоку.

Постановка задачі та методика розв'язування. Розглядаємо біматеріал, складений з двох півлощин $D_{1}$ і $D_{2}$, матеріали яких різні і характеризуються різними термомеханічними сталими: коефіцієнтами Пуассона $\left(v_{1}, v_{2}\right)$, модулями зсуву $\left(G_{1}, G_{2}\right)$, коефіцієнтами лінійного теплового розширення $\left(\alpha_{1}, \alpha_{2}\right)$ та коефіцієнтами теплопровідності $\left(\lambda_{1}\right.$, $\left.\lambda_{2}\right)$. На межі з'єднання півплощин розташована міжсразна щілина (рис. 1) завдовжки $2 a$ з початковою висотою $h_{0}(x)$, яка значно менша від довжини щілини $\left(h_{0}(x) / a \ll 1,|x| \leq a\right)$.

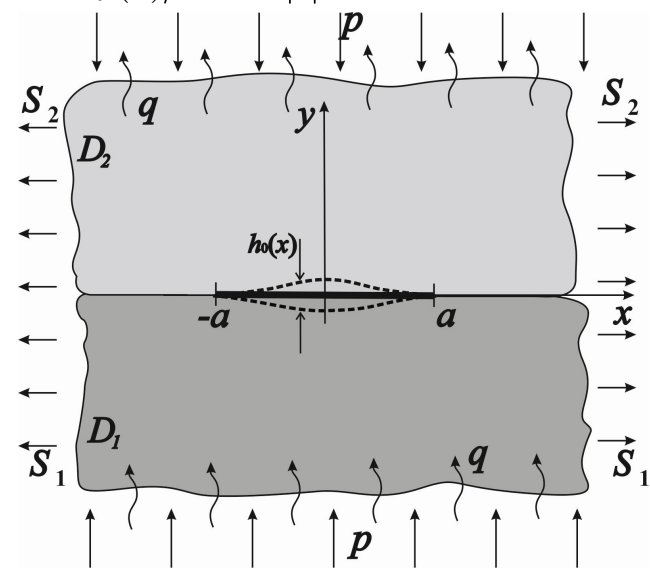

Рис. 1 - Схема біматеріалу 3 міжфазною щілиною, що закривається під дією навантаження

На нескінченності до біматеріалу прикладено рівномірно розподілене стискальне навантаження $p$ та стаціонарний тепловий потік $q$, а також лінійно розподілені по координаті $y$ напруження $S_{1}$ і $S_{2}$, які усувають глобальне видовження і викривлення півплощин під дією стискального навантаження i теплового потоку. Вважаємо, що береги щілини 
теплоізольовані і під дією стискальних зусиль контактують по всій ії довжині $[-a, a]$ без тертя (рис. 1).

На ділянках з'єднання півплощин поза щілиною виконуються умови ідеального теплового і механічного контакту.

Контактно-крайові умови сформульованої задачі матимуть вигляд:

- на ділянках контакту півплощин

$$
T^{+}=T^{-}, q_{y}^{+}=q_{y}^{-}, \sigma_{y}^{+}=\sigma_{y}^{-}, \tau_{x y}^{+}=\tau_{x y}^{-}, u^{+}=u^{-}, v^{+}=v^{-},
$$

- на ділянці щілини

$$
q_{y}^{+}=q_{y}^{-}, q_{y}^{-}=0, \sigma_{y}^{+}=\sigma_{y}^{-}, \sigma_{y}^{-}=-P(x), \tau_{x y}^{+}=0, \tau_{x y}^{-}=0,
$$

де $T$ - температура; $q_{y}$ - компонента вектора теплового потоку; $u, v$ - компоненти вектора переміщень; $\sigma_{y}, \tau_{x y}$ - компоненти тензора напружень; $P(x)$ - контактний тиск берегів щілини; індексами „+”, „-” позначено граничні значення величин у верхній і нижній півплощині відповідно.

Використовуючи викладену у [6] методику, температурне поле і напружено-дефрормований стан в біматеріалі подано через розкриття щілини $h(x)$ та стрибок температури між ії̈ берегами $\gamma(x)$ та стрибок дотичних переміщень $U(x)$ :

$$
\begin{gathered}
q_{y}^{+}=q_{y}^{-}=\frac{\lambda}{2 \pi} \int_{-a}^{a} \frac{\gamma^{\prime}(t) d t}{t-x}+q, \\
\sigma_{y}^{+}=\sigma_{y}^{-}=p+\lambda G_{1} G_{2}\left(\frac{\eta_{2}}{G_{2}+G_{1} \kappa_{2}}-\frac{\eta_{1}}{G_{1}+G_{2} \kappa_{1}}\right) \gamma(x)+ \\
+G_{1} G_{2}\left(\frac{G_{2}\left(1-\kappa_{1}\right)-G_{1}\left(1-\kappa_{2}\right)}{\left(G_{2}+G_{1} \kappa_{2}\right)\left(G_{1}+G_{2} \kappa_{1}\right)}\right) U^{\prime}(x)+ \\
+\frac{G_{1} G_{2}}{\pi}\left(\frac{G_{2}\left(1+\kappa_{1}\right)+G_{1}\left(1+\kappa_{2}\right)}{\left(G_{2}+G_{1} \kappa_{2}\right)\left(G_{1}+G_{2} \kappa_{1}\right)}\right) \int_{-a}^{a} \frac{h^{\prime}(t)}{t-x} d t, \\
\tau_{x y}^{+}=\tau_{x y}^{-}=\frac{\lambda G_{1} G_{2}}{\pi}\left(\frac{\eta_{2}}{G_{2}+G_{1} \kappa_{2}}+\frac{\eta_{1}}{G_{1}+G_{2} \kappa_{1}}\right) \int_{-a}^{a} \frac{\gamma(t)}{t-x} d t+
\end{gathered}
$$




$$
\begin{aligned}
& +G_{1} G_{2}\left(\frac{G_{2}\left(1-\kappa_{1}\right)-G_{1}\left(1-\kappa_{2}\right)}{\left(G_{2}+G_{1} \kappa_{2}\right)\left(G_{1}+G_{2} \kappa_{1}\right)}\right) h^{\prime}(x)- \\
& -\frac{G_{1} G_{2}}{\pi}\left(\frac{G_{2}\left(1+\kappa_{1}\right)+G_{1}\left(1+\kappa_{2}\right)}{\left(G_{2}+G_{1} \kappa_{2}\right)\left(G_{1}+G_{2} \kappa_{1}\right)}\right) \int_{-a}^{a} \frac{U^{\prime}(t)}{t-x} d t .
\end{aligned}
$$

Тут $\gamma(x)=0 ; U(x)=0 ; h(x)=0$, якщо $|x| \geq a$ (ззовні щілини).

Задовольняючи контактно-крайові умови (1), (2) за допомогою подань (3), (4), (5), отримаємо систему сингулярних інтегродиференціальних рівнянь (СІДР):

$$
\begin{gathered}
-\frac{\lambda}{2 \pi} \int_{-a}^{a} \frac{\gamma^{\prime}(t)}{t-x} d t=q,|x|<a, \\
\frac{1}{\pi} \int_{-a}^{a} \frac{U^{\prime}(t)}{t-x} d t-\lambda \eta^{+} \frac{1}{\pi} \int_{-a}^{a} \frac{\gamma(t)}{t-x} d t+\beta h_{0}^{\prime}(x)=0 \\
\text { де } \gamma( \pm a)=0, U( \pm a)=0 ; \lambda=\frac{2 \lambda_{1} \lambda_{2}}{\lambda_{1}+\lambda_{2}}, \beta=\frac{G_{2}\left(1-\kappa_{1}\right)-G_{1}\left(1-\kappa_{2}\right)}{G_{2}\left(1+\kappa_{1}\right)+G_{1}\left(1+\kappa_{2}\right)}, \\
\eta^{+}=\frac{\left(G_{2}+G_{1} \kappa_{2}\right) \eta_{2}+\left(G_{1}+G_{2} \kappa_{1}\right) \eta_{1}}{G_{2}\left(1+\kappa_{1}\right)+G_{1}\left(1+\kappa_{2}\right)} .
\end{gathered}
$$

Систему рівнянь (6), (7) розв'язано аналітично [6], і визначено функції $\gamma(x)$ і $U^{\prime}(x)$ :

$$
\begin{gathered}
\gamma(x)=\frac{2 q}{\lambda} \sqrt{a^{2}-x^{2}},|x|<a ; \\
U^{\prime}(\mathrm{x})=q \eta^{+}\left(2 \sqrt{a^{2}-x^{2}}-\frac{a^{2}}{\sqrt{a^{2}-x^{2}}}\right)+\frac{\beta}{\pi \sqrt{a^{2}-x^{2}}} \int_{-a}^{a} \frac{\sqrt{a^{2}-t^{2}} h_{0}^{\prime}(t)}{t-x} d t, \\
|x|<a .
\end{gathered}
$$

Враховуючи співвідношення (8), (9) у виразі (4), визначено контактний тиск берегів щілини $P(x)\left(P(x)=-\sigma_{y}^{+}\right)$:

$$
P(x)=p+\frac{q}{G^{*}}\left[\frac{\beta \eta^{+} a^{2}}{\sqrt{a^{2}-x^{2}}}-2\left(\eta^{-}+\beta \eta^{+}\right) \sqrt{a^{2}-x^{2}}\right]+
$$


де

$$
\begin{array}{r}
\left.+\frac{1}{G^{*} \pi} \int_{-a}^{a} \frac{\left[1-\beta^{2} \frac{\sqrt{a^{2}-t^{2}}}{\sqrt{a^{2}-x^{2}}}\right]}{t-x}\right] h_{0}^{\prime}(t) \\
\eta^{-}=\frac{\left(G_{2}+G_{1} \kappa_{2}\right) \eta_{2}-\left(G_{1}+G_{2} \kappa_{1}\right) \eta_{1}}{G_{2}\left(1+\kappa_{1}\right)+G_{1}\left(1+\kappa_{2}\right)}, \\
G^{*}=\frac{\left(G_{2}+G_{1} \kappa_{2}\right)\left(G_{1}+G_{2} \kappa_{1}\right)}{G_{1} G_{2}\left(G_{2}\left(1+\kappa_{1}\right)+G_{1}\left(1+\kappa_{2}\right)\right)} .
\end{array}
$$

Напружено-деформований стан біматеріалу в околі вершини щілини визначається коефіцієнтом інтенсивності дотичних міжфазних напружень:

$$
\begin{gathered}
K_{I I}=\lim _{x \rightarrow a}\left\{\sqrt{2 \pi(x-a)} \tau_{x y}(x)\right\}, \\
\text { де } \quad \tau_{x y}=\frac{q a^{2} \eta^{+}}{G^{*} \sqrt{x^{2}-a^{2}}}+\frac{\beta}{\pi G^{*}} \int_{-a}^{a} \frac{F(t)}{\sqrt{a^{2}-t^{2}}(t-x)} d t,|x|>a, \\
F(t)=\frac{1}{\pi} \int_{-a}^{a} \frac{\sqrt{a^{2}-\xi^{2}} h_{0}^{\prime}(\xi)}{\xi-t} d \xi .
\end{gathered}
$$

Аналіз результатів. На основі співвідношень (10), проаналізовано розподіл контактного тиску берегів щілини та залежність коефіцієнта інтенсивності дотичних напружень від теплового потоку.

Зауважимо, що значення стискальних зусиль при яких береги щілини контактують на всій ії̈ ділянці $€$ наперед невідомими. Відомо, що для того щоб щілина не розкривалася необхідно, щоб контактний тиск був додатнім $P(x)>0$. 3 цієї умови знайдемо діапазон зміни стискальних зусиль $p>p_{c r}$ при яких щілина буде закриватися на усій ділянці. Порогові значення зусиль $p_{c r}$ відповідно визначатимемо з умови коли найменше значення контактного тиску дорівнює нулю $(P(0)=0)$.

Розрахунки проведено для біматеріалу з компонентами $D_{1}-$ сплав нікелю Ni 200 та $D_{2}$ - неіржавіюча сталь AISI 304. Основні термомеханічні характеристики матеріалів наведені у табл. 1. 
Довжина і початкова висота щілини відповідно $2 a=2 м м$, $h_{0}(x)=0.001\left(1-(x / a)^{2}\right)^{3 / 2}$. Розглянуто два напрями теплового потоку: перший - коли тепловий потік скерований від матеріалу $D_{1}$ до матеріалу $D_{2}$, другий - від матеріалу $D_{2}$ до матеріалу $D_{1}$.

Таблиця 1 - Характеристики матеріалів

\begin{tabular}{|c|c|c|}
\hline Матеріал & $\begin{array}{c}D_{1}-\text { сплав нікелю } \\
\text { Ni } 200\end{array}$ & $\begin{array}{c}D_{2}-\text { неіржавіюча сталь } \\
\text { AISI } 304\end{array}$ \\
\hline Коефіцієнт Пуассона v & 0,264 & 0,2532 \\
\hline Модуль зсуву $G, M \Pi a$ & $80 \cdot 10^{3}$ & $86 \cdot 10^{3}$ \\
\hline $\begin{array}{c}\text { Коесріцієнт лінійного } \\
\text { теплового розширення } \alpha, 1 / K\end{array}$ & $1,33 \cdot 10^{-5}$ & $1,73 \cdot 10^{-5}$ \\
\hline $\begin{array}{c}\text { Коефріцієнт теплопровідності } \\
\lambda, \mathrm{Bm} \cdot \mathrm{MM} / \mathrm{K}\end{array}$ & $6,71 \cdot 10^{-2}$ & $1,63 \cdot 10^{-2}$ \\
\hline $\begin{array}{c}\text { Коефріцієнт термічної } \\
\text { дистортивності } \\
\eta, м M / K\end{array}$ & $0,2505 \cdot 10^{-3}$ & $1,3301 \cdot 10^{-3}$ \\
\hline
\end{tabular}

Графрічна ілюстрація результатів наведена на рис. 2 - рис. 4, де суцільні криві відображають випадок, коли тепловий потік скерований від сплаву нікелю до неіржавіючої сталі, а пунктирні - навпаки.

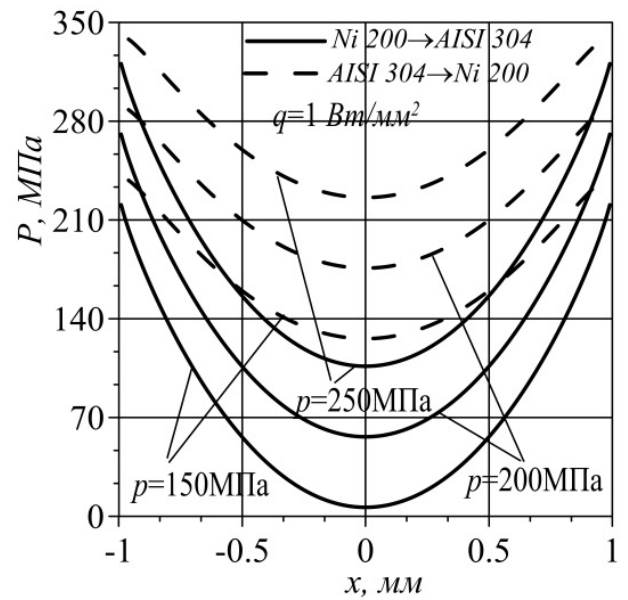

Рис. 2 - Розподіл контактного тиску $P(x)$ для різних значень інтенсивності стискальних зусиль $p$ та двох напрямів теплового потоку $q$ 
На рис. 2 зображено розподіл контактного тиску $P(x)$ вздовж щілини для різних значень інтенсивності стискальних зусиль $p$ та протилежних напрямів потоку $q$. Бачимо, що для фріксованого теплового потоку зі збільшенням силового навантаження контактний тиск зростає і є більший у випадку, коли тепловий потік скерований від неіржавіючої сталі до сплаву нікелю. Посередині щілини контактний тиск набуває локального мінімуму, що визначає порогове значення стискальних зусиль, за яких реалізується повне закриття щілини.

На рис. 3 побудовано залежність порогових значень стискальних зусиль $p_{c r}$ від густини та напряму теплового потоку. У випадку теплового потоку, скерованого від сплаву нікелю до неіржавіючої сталі, порогові значення зусиль зростають зі збільшенням густини теплового потоку. Для протилежного напряму теплового потоку збільшення густини потоку призводить до зменшення порогових значень стискальних зусиль. Зі збільшенням густини теплового потоку збільшується різниця у діапазоні зміни стискальних зусиль для двох протилежних напрямів потоку.

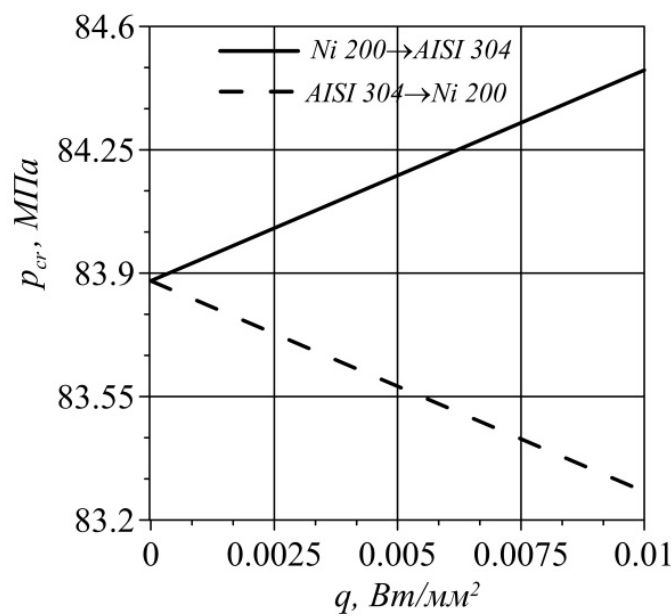

Рис. 3 - Залежність порогових значень стискальних зусиль $p_{c r}$ від густини теплового потоку $q$ для двох напрямів потоку

На рис. 4 проілюстровано залежність абсолютного значення коефіцієнта інтенсивності міжфазних дотичних напружень $\left|K_{\mathrm{II}}\right|$ від густини та напряму теплового потоку $q$. Бачимо, що коефріцієнт інтенсивності зростає зі збільшенням густини теплового потоку і набуває більших значень для потоку, скерованого від сплаву нікелю до неіржавіючої сталі. Це підтверджується тим, що термічна 
дистортивність неіржавіючої сталі $€$ більшою, і в дослідженнях, пов'язаних з міжфазною щілиною, було показано [6], що коефіцієнт інтенсивності дотичних міжфазних напружень завжди більший у випадку теплового потоку, скерованого до матеріалу з більшою термічною дистортивністю.

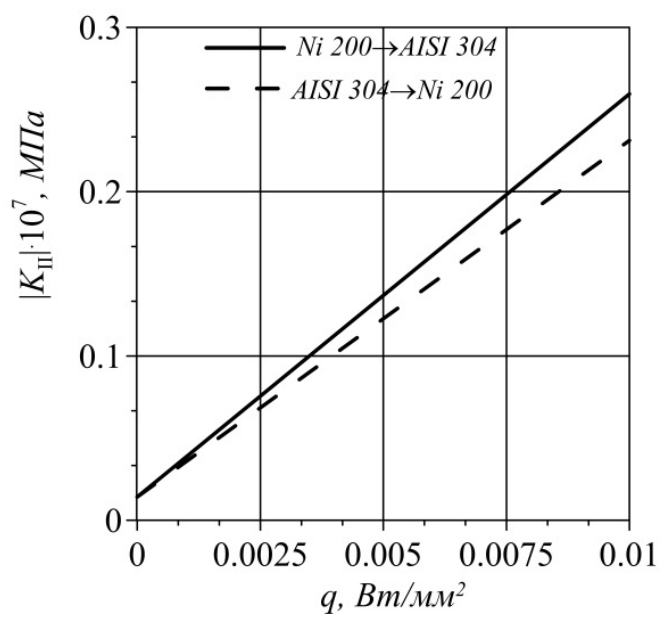

Рис. 4 - Залежність коефріцієнта інтенсивності міжфразних дотичних напружень $\left|K_{\text {II }}\right|$ від теплового потоку $q$

Висновки. Досліджено термопружну поведінку біматеріалу, складеного зі сплаву нікелю і неіржавіючої сталі за наявності міжфазної теплоізольованої щілини, береги якої контактують на всій їі ділянці під дією рівномірно розподілених стискальних зусиль та стаціонарного однорідного теплового потоку. Сформульовано задачу термопружності для такого біматеріалу, яку зведено до системи сингулярних інтегродиференціальних рівнянь відносно зсувних переміщень берегів щілини і стрибка температури між ії берегами. Побудовано аналітичний розв'язок системи і визначено функції стрибків у явному вигляді. Проаналізовано розподіл контактного тиску берегів щілини та залежність коефіцієнта інтенсивності дотичних напружень від теплового потоку. Визначено порогові значення і діапазон зміни стискальних зусиль, за яких щілина буде цілком закрита. Встановлено залежність інтенсивності зусиль від густини та напряму теплового потоку. Показано, що збільшення густини теплового потоку призводить до суттєво різних діапазонів зміни стискальних зусиль для двох протилежних напрямів потоку. Досліджено вплив зміни напряму теплового потоку на розподіл контактного тиску та коефріцієнт інтенсивності міжфазніх дотичних напружень. Встановлено, що контактний тиск берегів щілини буде більший у 
випадку теплового потоку, скерованого від неіржавіючої сталі до сплаву нікелю, а коефіцієнт інтенсивності дотичних міжфазних напружень $є$ більшим для протилежного напряму теплового потоку.

\section{БІБЛІОГРАФІЧНІ ПОСИЛАННЯ}

1. Гольдитейн Р.В., Кіт Г.С., Мартиняк Р.М., Середницька Х.І. Ефект часткового закриття міжфазної тріщини 3 теплопровідним заповнювачем і поверхневими плівками при дії на біматеріал термічного навантаження // Мат. методи та фіз.-мех. поля. 2012. Т. 55. № 4. С. 64-73.

2. Kim Г.С., Мартиняк Р.М. Термопружність кусково-однорідного тіла із закритою міжфазною тріщиною при наявності контактного термоопору між їі берегами // Доп. НАН України. 1996. № 10. С. 84-88.

3. Кіт Г.С., Мартиняк Р.М., Нагалка С.П. Термопружні ефекти в тілі з тріщиною, закритою зосередженими силами // Мат. методи та фіз.-мех. поля. 1999. Т. 42. № 2. C. 101-107.

4. Мартиняк P.M. Термопружний стан біматеріалу із закритою міжфазною тріщиною з шорсткими поверхнями // Мат. методи та фіз.-мех. поля. 2010. Т. 53, № 1. C.71-80.

5. Мартиняк P.М., Середницька Х.І. Термонапружений стан біматеріалу 3 періодичною системою міжфразних тріщин, заповнених теплопровідною речовиною // Фіз.-мат. моделювання та інформ. технології. 2014. Вип. 19. С. 168-175.

6. Мартиняк Р.М., Середницька Х.І. Контактні задачі термопружності для міжфазних тріщин в біматеріальних тілах. Львів: Растр-7, 2017. 168 с.

7. Харун І.В., Лобода В.В. Міжфазні тріщини з зонами контакту в полі зосереджених сил і моментів // Мат. методи та фріз.-мех. поля. 2002. Т. 45. № 2. С. 103-113.

8. Andreikiv A.O. Generalized Griffith problem of shear with regard for the roughness of the crack surfaces // Mater. Sci. 2000. Vol. 36. No. 2. P. 210-217.

9. Barber J.R. Comninou M. The penny-shaped interface crack with heat flow. Part 2: Imperfect contact // Trans. ASME. J. Appl. Mech. 1983. Vol. 50.No 4a. P. 770-776.

10. Feraille-Fresnet A., Bui H.-D., Ehrlacher A. Hydrostatic interaction of a wetting fluid and a circular crack in an elastic material // Mech. Mater. 2003. Vol. 35. P. 581-586.

11. Garsia A.M., Sehitoglu H. Contact of crack surfaces during fatigue: Part 1. Formulation of the model // Metallurgical and Materials Transactions. A. 1997. 28.A. No. 11. P. 2263-2275.

12. Gilbert C.J., Ritchie R.O. Mechanisms of cyclic fatigue crack propagation in a finegrained alumina ceramic: the role of cracks closure // Fatigue Fract. Engng. Mater. Struct. 1997. Vol. 20. No 10. P. 1453-1466.

13. Gross T.S., Mendelsohn D.A. On the effect of crack face contact and friction due to fracture surface roughness in edge crack subjected to external shear // Eng. Fract. Mech. 1988. Vol. 31. No 3. P. 405-420.

14. Loboda V., Lapusta Y., Sheveleva A. Limited permeable crack in an interlayer between piezoelectric materials with different zones of electrical saturation and mechanical yielding // Int. J. Solids Struct. 2010. No 47. P. 1795-1806.

15. Newman J.A., Piascik R.S. Interactions of plasticity and oxide crack closure mechanisms near the fatigue crack growth threshold // Int. J. Fatigue. 2004. Vol. 26. No 9. P. 923-927.

16. Riemelmoser F.O., Pippan R. Crack closure: a concept of fatigue crack growth under examination // Fatigue Fract. Eng. Mater. Struct. 1997. Vol. 20. No. 11. P. 15291540. 


\title{
ЗАДАЧА ТЕРМОУПРУГОСТИ ДЛЯ ЗАКРЫТОЙ МЕЖФАЗНОЙ ТЕПЛОИЗОЛИРОВАННОЙ ЩЕЛИ В РАЗНОРОДНОМ БИМАТЕРИАЛЕ
}

\begin{abstract}
Исследовано поведение разнородного биматериала с межфазной теплоизолированной щелью, берега которой контактируют по всей длине под действием сжимающих усилий и однородного теплового потока. Задача термоупругости сведена к системе сингулярных интегро-дифференциальных уравнений относительно скачка температуры и сдвиговых перемещений берегов щели. Полученная система решена для биматериала, составленного из сплава никеля и нержавеющей стали. Определено контактное давление берегов щели и пороговые значения сжимающих усилий, для которых происходит полное закрытие щели. Проанализировано влияние теплового потока на коэффициент интенсивности касательных напряжений.
\end{abstract}

Ключевые слова: термоупругость; разнородный биматериал; межфразная щель; закрытие щели; сжимающие усилия; тепловой поток.

UDC 539.3

Kh. I. Serednytska, PhD (Phys.-Math.)

\section{THERMAL ELASTIC PROBLEM FOR CLOSED INTERFACE THERMO-INSULATED CRACK IN DISSIMILAR BIMATERIAL}

The behavior of a dissimilar bimaterial with an interface thermo-insulated crack, the edges of which are in contact along its length under the action of compressive loads and a uniform heat flow, has been studied. The thermoelasticity problem is reduced to a system of singular integro-differential equations for the temperature jump and shear displacements of the crack edges. The resulting system is solved for a bimaterial composed of an alloy of nickel and stainless steel. The contact pressure of the edges of the crack and critical value of compressive loads, for which the crack is closed, are determined. The influence of heat flow on the Mode-II stress intensity factor is analyzed.

Keywords: thermo-elasticity; dissimilar biomaterial; interface crack; crack closure; compressive loads; heat flow.

In real materials, due to various physical, mechanical and chemical processes, the structure of body surfaces changes and various defects appear. The microstructure of the surfaces of bodies or defects determines the contact discreteness of the surfaces. The actual contact area depends on the contact pressure and changes with the load [11]. Contact problems for cracks have been studied taking into account surface roughness, the thin layers and the gaps filler [8,13,12, 15, 16, 10]. In the article [9] takes into account the microstructure of the surface in case of imperfect thermal contact with the thermal resistance. The thermo-elasticity of a piecewise homogeneous body with a closed interfacial crack in the presence of contact thermal resistance between its faces was studied in [2]. The crack closure under the action of concentrated force was analyzed for a homogeneous material [3]. The crack closure under the action of a uniformly distributed 
compressive loads and a uniform heat flow has been studied for a bimaterial whose components differ in shear modules [4]. In recent works, the dependence of contact heat transfer on surface roughness is taken into account. In papers $[1,5]$, the influence of thin films and crack filler on the partial contact of its faces under the action of heat flow and tensile load in a bimaterial with a zero Danders parameter is taken into account. In the above works, studies were mainly conducted for such bimaterials, the characteristics of which were partially variable, in particular, differed only in shear modules or Poisson's ratios or mechanical characteristics are the same and the like. Contact problems for heterogeneous bodies with interface cracks, the faces of which are in contact at the apical zones, have been investigated under the action of mechanical and electrical loads [7, 14]. In this article, the thermo-mechanical behavior of a heterogeneous bimaterial with an interface heat-insulated crack, which is completely closed under the action of compressive load and heat flow, is investigated. The bimaterial components consist of an alloy of nickel and stainless steel. We believe that the gap is initially open, but its shores may close completely under the action of compressive loads and heat flow. The range of change of the applied loading remains unknown. The thermo-elasticity problem is reduced to a system of singular integro-differential equations for the jump of temperature and jump of tangential displacements of the faces crack. To determine the critical loads, we use the condition of smooth contact of the crack faces. The system of equations is solved analytically and the temperature jump and shear displacements are explicitly defined. The contact pressure of the faces crack and the tangential interface stresses are determined. The distribution of contact pressure along the crack is analyzed. Contact pressure increases with increasing compressive loads at a fixed value of heat flow density. It is also shown that changing the direction of heat flow affects the distribution of contact pressure. The critical load values at which the crack is completely closed are determined. The dependence of compressive loads on the density and direction of heat flow is established. As the heat flow density increases, the difference between the compressive loads values for the two opposite flow directions increases. The influence of the density and direction heat flow on the Mode-II stress intensity factor is analyzed. The intensity factor is higher when the heat flow is directed from the alloy of nickel to stainless steel. The latter phenomenon can be explained by the fact that the heat flowing into the material with bigger thermal distortivity.

\section{REFERENCES}

1. Goldstein R.V., Kit H.S., Martynyak R.M., Serednytska Kh.l. Effect of Partial Closure of an Interface Crack with Heat-conducting Filler and Surface Films in the Case of Thermal Loading of a Bimaterial // Mathematical Methods and Physico-mechanical Filds. 2012. Vol. 55. No 4. P. 64-73. (in Ukrainian).

2. Kit H.S., Martynyak R.M. Thermoelasticity of a piecewise homogeneous body with a closed interface crack in the presence of contact thermal resistance between its faces // Reports of the NAS of Ukraine. 1996. No 10. P. 84-88. (in Ukrainian). 
3. Kit H.S., Martynyak R.M., Nagalka S.P. Thermoelastic effects in a body with a crack closed by concentrated forces // Mathematical Methods and Physico-mechanical Filds. 1999. Vol. 42. No 2. P. 101-107. (in Ukrainian).

4. Martynyak R.M. Thermal stressed state in bimaterial with a closed interface crack with rough surfaces // Mathematical Methods and Physico-mechanicaL Filds. 2010. Vol. 53. No1. P.71-80. (in Ukrainian).

5. Martynyak R.M., Serednytska Kh.I. Thermoelastic state of bimaterial with periodic system of interfacial cracks filled heat-conductive medium // Physical-mathematical modeling and information technologies. 2014. Vol. 19. P. 168-175. (in Ukrainian).

6. Martynyak R.M., Serednytska Kh.l. Contact problems of thermoelasticity for interface cracks in bimaterials. Lviv : Rastr-7, 2017. 168 p. (in Ukrainian).

7. Kharun I.V., Loboda V.V. Interface cracks with contact zones in a field of concentratedforces and torques // Mathematical Methods and Physico-mechanical Filds. 2002. Vol. 45. No 2. P. 103-113.

8. Andreikiv A.O. Generalized Griffith problem of shear with regard for the roughness of the crack surfaces // Mater. Sci. 2000. Vol. 36. No 2. P. 210-217.

9. Barber J.R., Comninou M. The penny-shaped interface crack with heat flow. Part 2: Imperfect contact // Trans. ASME. J. Appl. Mech. 1983. Vol.50. No 4a. P. 770-776.

10. Feraille-Fresnet A., Bui H.-D., Ehrlacher A. Hydrostatic interaction of a wetting fluid and a circular crack in an elastic material // Mech. Mater. 2003. Vol. 35. P. 581-586.

11. Garsia A.M., Sehitoglu H. Contact of crack surfaces during fatigue: Part 1. Formulation of the model // Metallurgical and Materials Transactions. A. 1997. 28A. No. 11. P. 2263-2275.

12. Gilbert C.J., Ritchie R.O. Mechanisms of cyclic fatigue crack propagation in a finegrained alumina ceramic: the role of cracks closure // Fatigue Fract. Engng. Mater. Struct. 1997. Vol. 20. No 10. P. 1453-1466.

13. Gross T.S., Mendelsohn D.A. On the effect of crack face contact and friction due to fracture surface roughness in edge crack subjected to external shear // Eng. Fract. Mech. 1988. Vol. 31. No 3. P. 405-420.

14. Loboda V., Lapusta Y., Sheveleva A. Limited permeable crack in an interlayer between piezoelectric materials with different zones of electrical saturation and mechanical yielding // Int. J. Solids Struct. 2010. No 47. P. 1795-1806.

15. Newman J.A., Piascik R.S. Interactions of plasticity and oxide crack closure mechanisms near the fatigue crack growth threshold // Int. J. Fatigue. 2004. Vol. 26. No 9. P. 923-927.

16. Riemelmoser F.O., Pippan R. Crack closure: a concept of fatigue crack growth under examination // Fatigue Fract. Eng. Mater. Struct. 1997. Vol. 20. No 11. P. 15291540.

Інститут прикладних проблем

механіки і математики

ім. Я.С. Підстригача НАН України,

Львів, Україна

Надійшла до редколеаії 05.10.2020 